\title{
MANAJEMEN PENINGKATAN MUTU SD NEGERI 1 GUMELAR SEBAGAI SEKOLAH UNGGULAN DI KECAMATAN GUMELAR KABUPATEN BANYUMAS
}

\author{
Yusep Kurniawan*, Ana Andriani, Tukiran Taniredja \\ Program Studi Magister Pendidikan Dasar, Universitas Muhammadiyah \\ Purwokerto \\ *yusepkurniawan88@gmail.com
}

Accepted: 29 Februari 2020

\begin{abstract}
This research aims to: 1) find out how the management of improving the quality of SD Negeri 1 Gumelar as a superior school; 2) find out the impact of school quality improvement management on student achievement; 3) find out the impact of school quality improvement management on the results of USBN grade VI students. Research activities carried out at SD 1 Gumelar Elementary School. The study was conducted for 4 (four) months, starting from March until June 2019. This research is a descriptive study with qualitative and quantitative approaches. Data collection techniques and tools were carried out by distributing questionnaires and interviews. Data analysis was carried out qualitatively and quantitatively. The results of the study show that: 1) Gumelar Elementary School 1 has implemented management of quality improvement in eight national education standards well and optimally. Management of quality improvement that has not been optimal can be seen in graduate competency standards, educator standards and education staff as well as standards of facilities and infrastructure. 2) The management of quality improvement carried out has a very good impact on student achievement. It was proven that SD Negeri 1 Gumelar became the overall champion in the race activities at the subdistrict level in 2019. 3) The results of the study showed that the management of quality improvement had no impact on the results of USBN for Grade VI students in 2018 and 2019. The results of USBN in 2019 only reached 25 Gumelar District.
\end{abstract}

Keywords: Management; Quality Improvement; Leading Schools

\section{PENDAHULUAN}

Lembaga pendidikan memerlukan pengelolaan atau manajemen yang baik agar memiliki pelayanan pendidikan yang bermutu. Lembaga pendidikan salah satunya adalah sekolah atau satuan pendidikan, baik formal maupun non formal. Sekolah sebagai penyelenggara pendidikan tentu harus memiliki pelayanan yang berkualitas. Manajemen sekolah yang baik dilakukan dengan memberdayakan seluruh sumber daya sekolah secara optimal. Optimalisasi sumber daya sekolah menjadi pendukung terlaksananya manajemen sekolah. Manajemen yang baik dapat mewujudkan terjaganya mutu sebuah sekolah.

Sekolah sebagai sistem penjaminan mutu internal berkewajiban menjamin mutu pendidikan melalui manajemen mutu sekolah. Dalam peningkatan mutu

Y. Kurniawan, A. Andriani \& T. Taniredja, Manajemen Peningkatan Mutu SD Negeri 1 Gumelar Sebagai Sekolah Unggulan di Kecamatan Gumelar Kabupaten Banyumas 
sekolah, sekolah perlu menjamin melalui implementasi penyelenggaraan pendidikan di sekolah dengan mengacu Standar Nasional Pendidikan (SNP). Permendikbud No. 28 Tahun 2016 tentang Sistem Penjaminan Mutu Pendidikan Dasar dan Menengah dalam pasal 17 ayat (1) bahwa data dan informasi mutu pendidikan sesuai dengan delapan Standar Nasional Pendidikan (SNP). Dalam Standar Nasional Pendidikan (SNP), terdapat delapan standar yang harus dipenuhi sekolah, diantaranya: 1) Standar Kompetensi Lulusan, 2) Standar Isi; 3) Standar Proses; 4) Standar Penilaian Pendidikan; 5) Standar Pendidik dan Tenaga Kependidikan; 7) Standar Sarana dan Prasarana; 6) Standar Pengelolaan; dan 8) Standar Pembiayaan. Kedelapan standar tersebut perlu dipenuhi sekolah untuk menjaga mutu pendidikan.

Terwujudnya keberhasilan pembangunan pendidikan nasional menurut Mustari dan Rahman (2014:237) merupakan dasar setiap lembaga pendidikan memprioritaskan manajemen pendidikan. Sutapa dan Andriani (2014:82) juga menjelaskan bahwa manajemen pendidikan merupakan komponen yang sangat penting dalam menentukan keberhasilan sekolah dalam peningkatan mutu. Fauzi A (2017:54) menjelaskan bahwa manajemen merupakan salah satu aspek terpenting dalam pengelolaan sekolah. Beberapa kajian tentang manajemen pendidikan tersebut menjadi dasar bahwa manajemen merupakan salah satu aspek penting dalam peningkatan mutu sekolah.

Hasil penelitian Setyaningsih (2017:139) menjelaskan bahwa mutu sekolah tidak hanya ditandai dengan capaian hasil dari nilai ujian dan tingginya tingkat kelulusan peserta didik. Indikator tersebut merupakan salah satu capaian hasil dari mutu input dan proses suatu sekolah. Mutu sekolah berarti mencakup seluruh aspek manajemen di sekolah, merujuk pada proses penyelenggaraan pendidikan bukan hanya pada hasil dari penyelenggaraan pendidikan.

Pemantauan pemerintah terhadap mutu sekolah selain melalui sistem penjaminan mutu pendidikan juga dilakukan melalui akreditasi sekolah. Akreditasi sekolah dilaksanakan secara periodik dalam kurun waktu lima tahunan. Badan Akreditasi Nasional Sekolah/Madrasah melaporkan hasil akreditasi sekolah dasar Kabupaten Banyumas pada tahun 2018 berjumlah 58 sekolah. Dari jumlah tersebut terdapat 31 atau $53,4 \%$ sekolah dengan hasil akreditasi A, 23 atau 39,7\% sekolah terakreditasi B, 3 atau 5,2\% sekolah terakreditasi C dan 1 atau 1,7\% sekolah terakreditasi $\mathrm{D}$ dan 0 atau $0 \%$ sekolah terakreditasi $\mathrm{E}$. Hasil akreditasi tersebut menunjukkan bahwa di Kabupaten Banyumas masih terdapat 45,6\% sekolah yang belum terakreditasi A. Badan Akreditasi Nasional Sekolah/Madrasah yang selanjutnya disingkat BAN-SM mengkategorikan sekolah yang terakreditasi $\mathrm{A}$ sebagai sekolah kategori unggul, terakreditasi B kategori baik, terakreditasi C kategori cukup dan untuk sekolah yang hasil akreditasi dengan kategori $\mathrm{D}$ dan $\mathrm{E}$ dianggap sebagai sekolah yang belum terakreditasi.

Y. Kurniawan, A. Andriani \& T. Taniredja, Manajemen Peningkatan Mutu SD Negeri 1 Gumelar Sebagai Sekolah Unggulan di Kecamatan Gumelar Kabupaten Banyumas 
Hasil akreditasi SD Negeri di Kabupaten Banyumas menjadi dasar peneliti untuk menggali informasi lebih mendalam mengenai hasil akreditasi Sekolah Dasar di wilayah Kecamatan Gumelar. Hasil studi awal, berdasarkan informasi yang dirujuk dari data di BAN-SM, menunjukkan bahwa sekolah dasar di Kecamatan Gumelar yang diakreditasi pada tahun 2018 hanya satu sekolah. Oleh sebab itu peneliti dalam studi awal mencoba untuk menggali informasi mengenai hasil akreditasi Sekolah Dasar se- Kecamatan Gumelar pada tahun 2017.

Hasil akreditasi sekolah dasar di Kecamatan Gumelar tahun 2017 menunjukkan tidak semua dalam kategori nilai akreditasi A. Data BAN-SM menunjukkan bahwa terdapat 8 SD Negeri dari 32 SD Negeri di Kecamatan Gumelar yang diakreditasi tahun 2017. Hasil akreditasi menunjukkan terdapat 5 Sekolah Dasar dengan kategori nilai akreditasi B dan 3 SD dengan kategori nilai akreditasi A. Kondisi sekolah yang belum memperoleh hasil akreditasi maksimal disebabkan karena belum optimalnya manajemen delapan standar nasional pendidikan yang menjadi dasar penilaian akreditasi sekolah. Delapan Sekolah Dasar tersebut yaitu: SD Negeri 1 Gumelar, SD Negeri 1 Tlaga, SD Negeri 1 Samudra, SD Negeri 2 Samudra, SD Negeri 2 Samudra Kulon, dan SD Negeri 1 Cilangkap, SD Negeri 4 Karangkemojing, SD Negeri 2 Paningkaban Kecamatan Gumelar. Informasi dari Pengawas TK/SD Korwilcam Dindik Kecamatan Gumelar bahwa SD Negeri 1 Gumelar merupakan sekolah dasar paling unggul di Kecamatan Gumelar. SD Negeri 1 Gumelar merupakan salah satu sekolah dari tiga sekolah yang terakreditasi A pada tahun 2017.

Latar belakang yang telah diuraikan menunjukkan bahwa mutu sekolah jika dilihat dari hasil akreditasi pada tahun 2017 lebih banyak Sekolah Dasar di Kecamatan Gumelar yang memiliki hasil akreditasi B (baik) dari pada A (unggul). Informasi studi awal menjadi salah satu dasar peneliti untuk menggali informasi lebih mendalam mengenai manajemen peningkatan mutu Sekolah Dasar yang paling unggul di Kecamatan Gumelar. Untuk itu, peneliti akan melakukan kegiatan penelitian berkaitan dengan manajemen peningkatan mutu SD Negeri 1 Gumelar Kecamatan Gumelar Kabupaten Banyumas. Berdasarkan latar belakang tersebut, peneliti tertarik untuk melakukan penelitian dengan judul "Manajemen Peningkatan Mutu SD Negeri 1 Gumelar sebagai Sekolah Unggulan di Kecamatan Gumelar Kabupaten Banyumas".

\section{METODE PENELITIAN}

Penelitian telah dilaksanakan dari bulan Maret sampai Juni 2019. Subjek dalam penelitian ini yaitu SD Negeri 1 Gumelar Kecamatan Gumelar. Objek dalam penelitian ini yaitu manajemen peningkatan mutu delapan standar nasional pendidikan SD Negeri 1 Gumelar Kecamatan Gumelar.

Y. Kurniawan, A. Andriani \& T. Taniredja, Manajemen Peningkatan Mutu SD Negeri 1 Gumelar Sebagai Sekolah Unggulan di Kecamatan Gumelar Kabupaten Banyumas 
Penelitian ini merupakan penelitian deskriptif menggunakan pendekatan kualitatif dan kuantitatif. Sugiyono (2014:205) menjelaskan bahwa penelitian kualitatif adalah penelitian yang mendeskripsikan dan menguraikan data hasil penelitian ke dalam bentuk tertulis secara rinci, komprehensif, dan luas, sedangkan penelitian kuantitatif merupakan salah satu jenis penelitian yang spesifikasinya adalah sistematis, terencana dan terstruktur dengan jelas sejak awal hingga pembuatan desain penelitiannya. Berdasarkan pendekatan dalam penelitian ini, maka kegiatan penelitian ini dilaksanakan untu menggambarkan bagaimana manajemen peningkatan mutu delapan standar nasional pendidikan SD Negeri 1 Gumelar.

\section{HASIL DAN PEMBAHASAN PENELITIAN}

Hasil penelitian menyajikan tentang manajemen peningkatan mutu SD Negeri 1 Gumelar perihal delapan Standar Nasional Pendidikan (SNP). Data diperoleh dari angket tak langsung tertutup dan wawancara tak terstruktur. Hasil penelitian dipaparkan sebagai berikut:

1. Manajemen Peningkatan Mutu SD Negeri 1 Gumelar sebagai Sekolah Unggulan

a. Manajemen Standar Kompetensi Lulusan

Hasil perhitungan skor angket menunjukkan persentase $90 \%$ dengan kategori sangat baik untuk responden kepala sekolah dan $91 \%$ dengan kategori sangat baik untuk responden guru (Gambar 1).

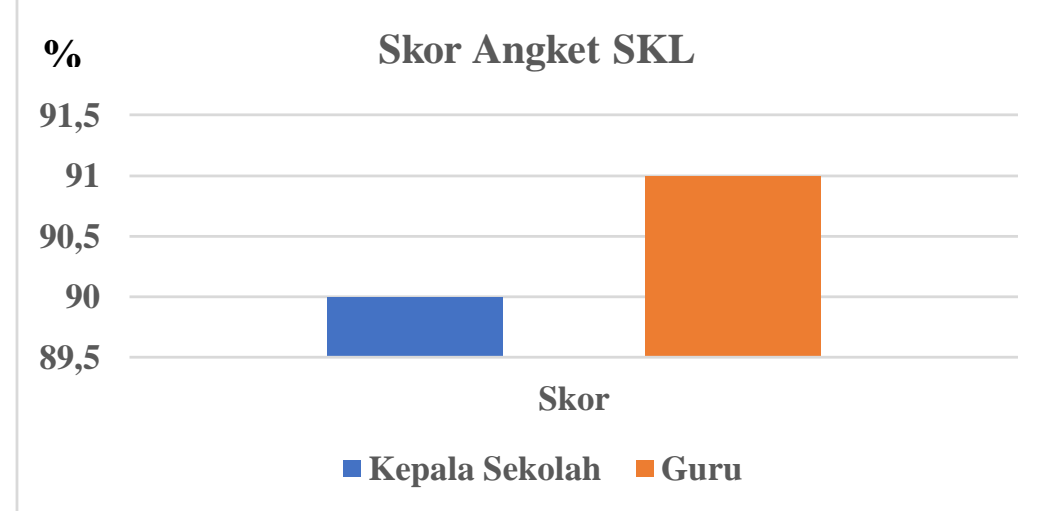

Gambar 1. Diagram Hasil Manajemen Standar Kompetensi Lulusan SD Negeri 1 Gumelar

Gambar 1 menunjukkan bahwa manajemen peningkatan mutu dari hasil rekapitulasi angket untuk standar kompetensi lulusan dari responden kepala sekolah dan guru menunjukkan kategori sangat baik. Angket dari responden kepala sekolah menunjukkan bahwa dari 15 pernyataan, hanya satu pernyataan yaitu pernyataan "siswa memiliki perilaku pembelajar sejati sepanjang hayat" dengan skor 3 , selain itu mendapat skor 4 . Angket dengan responden guru dengan skor maksimal adalah 42, berdasarkan rekapitulasi hasil angket menunjukkan skor

Y. Kurniawan, A. Andriani \& T. Taniredja, Manajemen Peningkatan Mutu SD Negeri 1 Gumelar Sebagai Sekolah Unggulan di Kecamatan Gumelar Kabupaten Banyumas 
tertinggi 31 dan terendah 24. Angket guru terdapat 11 indikator pernyataan, dari 11 indikator pernyataan tersebut terlihat pada indikator ke-6 memperoleh skor terendah yaitu 24. Pernyataan indikator ke- 6 yaitu "Kepala sekolah memfasilitasi siswa untuk memiliki keterampilan berpikir dan bertindak kreatif, produktif, kritis, mandiri, kolaboratif, dan komunikatif melalui pengalaman pembelajaran dan di dalam atau di luar kelas, misalnya praktik di laboratorium; penelitian sederhana; studi wisata; seminar atau workshop; peragaan atau pameran; dan pementasan karya seni." Delapan orang guru yang menjadi responden, semua guru memberikan skor 3 untuk indikator tersebut.

Kategori sangat baik pada angket guru ternyata relevan dengan hasil wawancara dari informan kepala sekolah untuk standar kompetensi lulusan dengan pertanyaan "apakah yang dilakukan bapak selaku kepala sekolah dalam melaksanakan fungsi manajerial untuk meningkatkan standar kompetensi lulusan sekolah? Jawaban dari kepala sekolah yaitu: "Secara umum sebagai kepala sekolah pertama memberikan dukungan kepada para guru untuk meningkatkan kualitas pembelajaran. Strategi yang dilakukan sesuai dengan kondisi atau kontekstual. Secara prinsip guru diupayakan optimal dalam memfasilitasi kegiatan pembelajaran serta semua kegiatan dalam upaya meningkatkan nilai-nilai yang ada di sekolah, seperti nilai sikap spritiaual, sosial yang bekelanjutan sepanjang hayat. Guru juga diupayakan mampu meningkatkan aktivitas siswa berkaitan upaya meningkatkan kompetensi pengetahuan, faktul dan konseptual maupun keterampilan.

Upaya lain terkait untuk meningkatkan mutu sekolah yaitu memfaslitasi agar siswa-siswi produktif dengan mengutamakan prinsip kebersamaan yang harus dibangun melalui nilai-nilai kolabolaratif." Transkrip wawancara tersebut menunjukkan bahwa kepala sekolah telah melakukan upaya melaksanakan manajemen peningkatan mutu sekolah, dalam hal ini pada standar kompetensi lulusan sekolah.

Hasil wawancara dari kepala sekolah juga ternyata didukung oleh hasil wawancara terhadap guru. Hasil wawancara terhadap dua orang guru, untuk manajemen standar kompetensi lulusan menunjukkan bahwa guru di SDN 1 Gumelar berupaya keras dan sungguh-sungguh untuk tercapainya kualitas lulusan yang berprestasi. Hal itu terlihat dari hasil observasi yang menunjukkan banyaknya prestasi kejuaraan lomba baik akademik maupun non akademik sekolah.

Hasil wawancara menunjukkan bahwa kepala sekolah dalam melaksanakan fungsi manajerial terhadap pengelolaan standar kompetensi lulusan dengan optimal. Tiga kompetensi lulusan yaitu sikap, pengetahuan dan keterampilan telah difasilitasi dengan baik dan optimal baik pada kegiatan kurikuler, kokurikuler maupun ekstrakurikuler.

Y. Kurniawan, A. Andriani \& T. Taniredja, Manajemen Peningkatan Mutu SD Negeri 1 Gumelar Sebagai Sekolah Unggulan di Kecamatan Gumelar Kabupaten Banyumas 
Hasil wawancara dengan guru kelas $\mathrm{VI}$ menunjukkan bahwa terdapat beberapa hambatan guru kelas VI dalam meraih prestasi lulusan terbaik. Hambatan yang dihadapi berasal dari faktor intrinsik dan ekstrinsik siswa. Faktor intrinsik siswa yang paling dominan mempengaruhi adalah motivasi belajar siswa yang rendah. Faktor ekstrinsik siswa yang menjadi penghambat guru dalam memberikan materi dan memfasilitasi siswa memahami materi ajar yang paling dominan yaitu siswa lebih asyik bermain game online di rumah daripada belajar. Menurut penjelasan dari guru kelas VI faktor intrinsik dan ekstrinsik tersebut saling berpengaruh.

Berdasarkan hasil angket menunjukkan bahwa manajemen standar kompetensi lulusan menunjukkan bahwa manajemen standar komptensi lulusan SD Negeri 1 Gumelar telah dilaksanakan dengan baik dan optimal. Terbukti bahwa SD Negeri 1 Gumelar menyabet banyak prestasi lomba baik akademik maupun non akademik di tahun 2018 dan 2019. Hasil Observasi menunjukkan bahwa nilai USBN dan Ujian Sekolah SD Negeri 1 Gumelar untuk tahun 2018 dan 2019 belum mencapai hasil yang maksimal. Kondisi tersebut juga disampaikan oleh guru kelas VI pada kegiatan wawancara. Bahwa terdapat hambatan dalam mengantarkan siswa kelas VI untuk meraih hasil ujian yang maksimal. Guru kelas VI juga menjelaskan bahwa kondisi tersebut akan terus menjadi bahan evaluasi dan perbaikan di tahun-tahun berikutnya.

b. Manajemen Standar Isi

Hasil perhitungan skor angket manajemen standar isi menunjukkan persentase $98 \%$ untuk responden kepala sekolah dan $91 \%$ untuk responden guru (Gambar 2).

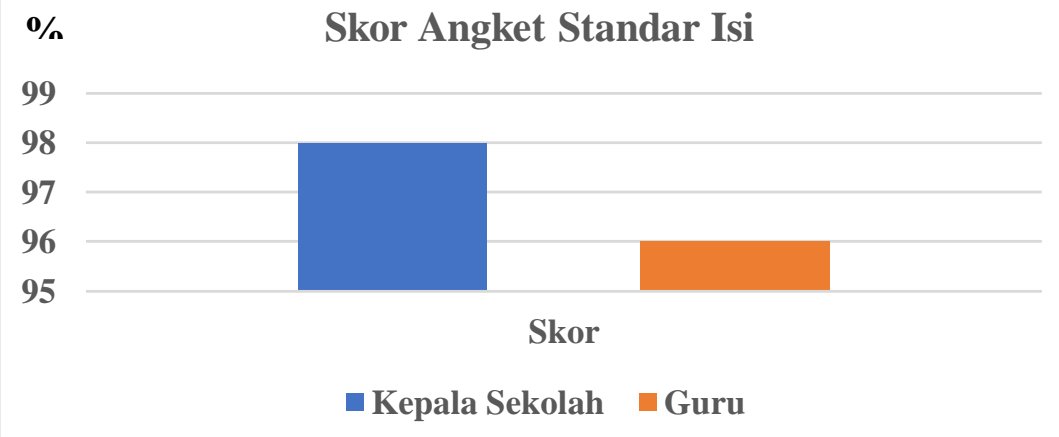

Gambar 2. Diagram Hasil Manajemen Standar Isi SD Negeri 1 Gumelar

Gambar 2 menunjukkan bahwa manajemen peningkatan mutu dari hasil rekapitulasi angket untuk standar isi berada dalam kategori sangat baik. Kategori sangat baik menunjukkan bahwa manajemen standar isi SD Negeri 1 Gumelar sudah dilaksanakan dengan sangat baik jika dilihat dari hasil angket. Hasil angket standar isi dengan responden kepala sekolah menunjukkan bahwa semua pernyataan dalam angket memperoleh skor 4 (maksimal). Hasil angket standar isi untuk responden guru terdapat 20 pernyataan. Skor tertinggi adalah 31 dan skor terendah 24. Skor terendah terdapat pada pernyataan angket nomor 16 yaitu :

Y. Kurniawan, A. Andriani \& T. Taniredja, Manajemen Peningkatan Mutu SD Negeri 1 Gumelar Sebagai Sekolah Unggulan di Kecamatan Gumelar Kabupaten Banyumas 
"Kepala sekolah mengelola perangkat pembelajaran yang dikembangkan untuk semua mata pelajaran sesuai dengan tingkat kompetensi dan ruang lingkup materi pembelajaran."

Hasil wawancara dari informan kepala sekolah mengenai manajemen standar isi dengan pertanyaan: "Terkait dengan standar isi, bagaimana upaya bapak selaku kepala sekolah untuk meningkatkan mutu standar isi? Jawaban dari informan yaitu: "Secara prinsip dasarnya adalah memfasilitasi peranan guru diutamakan agar bias senantiasa mengembangkan potensinya agar memiliki sikap sosial dan spiritual serta pengetahuan melalui kegiatan workshop, seminar, pelatihan dan KKG bagi guru kelas. Dari sisi kurikulum harus disusun agar bisa dilaksanakan dengan baik melalui Tim Pengembang Kurikulum."

Hasil wawancara dengan informan guru dengan pertanyan "Apakah guru di sekolah bapak dilibatkan dalam pengelolaan standar isi sekolah? Jawaban dari informan adalah "Guru-guru di SD Negeri 1 Gumelar ikut dilibatkan dalam manajemen standar isi. Salah satu contoh adalah guru ikut menjadi Tim Pengembang Kurikulum Sekolah (TPKS).

Hasil angket dan wawancara menunjukkan hubungan yang saling terkait dan mendukung satu sama lain. Hasil angket yang menunjukkan kategori manajemen standar isi sangat baik, didukung dengan wawancara dengan informan kepala sekolah dan guru. Kepala sekolah melaksanakan manajemen standar isi dan melibatkan guru dalam pelaksanaannya. Pelibatan guru menjadi faktor yang sangat penting, karena guru sebagai pelaksana kurikulum tentu sangat mengatahui secara praktis keadaan sekolah baik dari peserta didik maupun sarana dan prasarana sekolah. berdasarkan data angket dan wawancara mengenai manajemen standar isi yang telah dipaparkan tersebut dapat dilihat bahwa manajemen standar isi SDN 1 Gumelar dilaksanakan dengan sangat baik.

c. Manajemen Standar Proses

Hasil perhitungan skor angket manajemen standar proses menunjukkan persentase $92 \%$ untuk responden kepala sekolah dan 93\% untuk responden guru (Gambar 3).

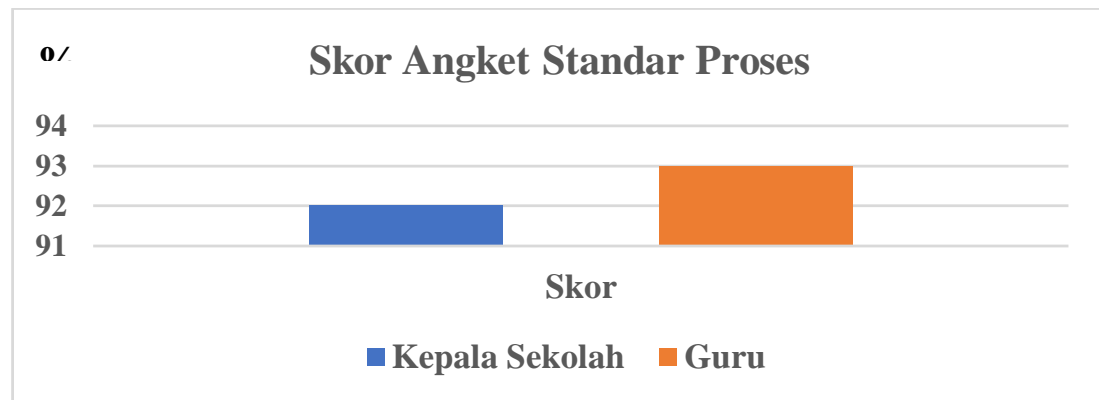

Gambar 3. Diagram Hasil Manajemen Standar Proses SD Negeri 1 Gumelar

Gambar 3 menunjukkan bahwa manajemen peningkatan mutu dari hasil rekapitulasi angket untuk standar proses berada dalam kategori sangat baik. Hasil

Y. Kurniawan, A. Andriani \& T. Taniredja, Manajemen Peningkatan Mutu SD Negeri 1 Gumelar Sebagai Sekolah Unggulan di Kecamatan Gumelar Kabupaten Banyumas 
angket standar proses dengan responden kepala sekolah terdapat 24 pernyataan ke-7 memperoleh skor 3, pernyataan itu memperoleh skor 4. Hasil angket standar proses dengan responden guru terdapat 14 pernyataan. Skor terendah 27 dan tertinggi 32. Skor terendah ditunjukan oleh pernyataan ke-2 yaitu "Kepala sekolah memfasilitasi kegiatan penyusunan RPP yang mengintegrasikan PPK dan GLS". Skor tertinggi ditunjukkan oleh pernyataan ke-3 yaitu "Kepala sekolah menetapkan alokasi waktu dan beban belajar di sekolah sesuai ketentuan".

Hasil wawancara dari informan kepala sekolah juga memperlihatkan kepala sekolah telah melaksanakan fungsi manajerial pada pengelolaan standar proses dengan sangat baik dan optimal. Kondisi tersebut terlihat pada jawaban yang diutarakan oleh kepala sekolah bahwa secara umum untuk dapat mewujudkan hasil yang baik tentu memerlukan proses yang baik. Kami selaku kepala sekolah selalu berusaha untuk memfasilitasi keberadaan sarana dan prasarana pendukung pelaksanaan proses pembelajaran dan penyelenggaraan pendidikan. Sebagai contoh perihal kecukupan buku, bahan ajar dan media ajar, selain itu juga memperkuat aspek penilaian yang prosedural, penyusunan soal yang berkualitas. Kegiatan lain seperti penetapan KKM juga harus dilakukan secara procedural, sistematis, dengan baik agar penilaian dapat dipertanggungjawabkan.

Hasil wawancara terhadap guru mengenai manajemen standar proses terlihat bahwa kepala sekolah melaksanakan pemantauan secara rutin terhadap kegiatan proses pembelajaran, ekstrakurikuluer, kokurikuler dan kegiatan lainnya di sekolah. Pemantauan dilakukan secara periodik, menurut keterangan dari informan guru pemantauan secara langsung dilakukan 2 kali dalam tiap semester.

Hasil penelitian tersebut dapat menjadi dasar bahwa manajemen standar proses telah dilaksanakan dengan sangat baik. Kepala sekolah telah melaksanakan fungsi manajerialnya dengan optimal. Proses penyelenggaraan sekolah juga dipantau secara periodik, terprogram dan sistematis.

d. Manajemen Standar Penilaian Pendidikan

Hasil perhitungan skor angket untuk responden kepala sekolah dan guru menunjukkan persentase 100\% untuk responden kepala sekolah dan $93 \%$ untuk responden guru (Gambar 4).

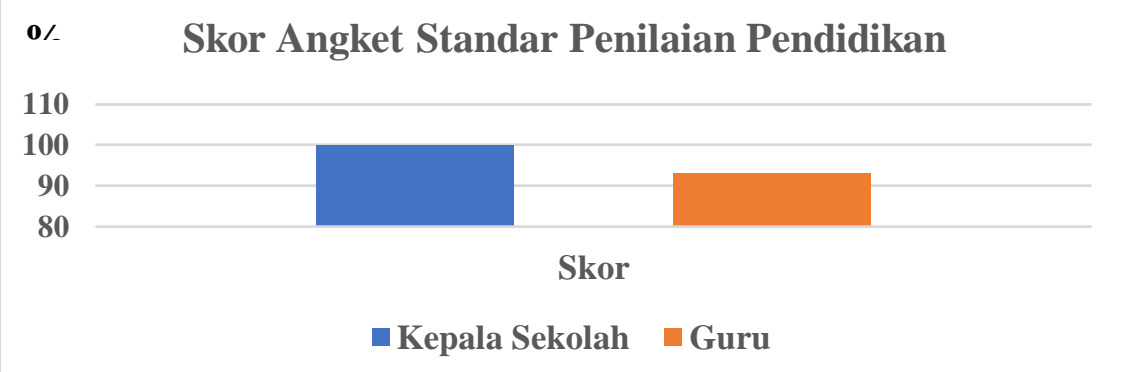

Gambar 4. Diagram Hasil Manajemen Standar Penilaian Pendidikan SD Negeri 1 Gumelar 
Gambar 4 menunjukkan bahwa manajemen peningkatan mutu dari hasil rekapitulasi angket untuk standar penilaian pendidikan baik responden kepala sekolah maupun guru menunjukkan kategori sangat baik. Kondisi tersebut didukung oleh lengkapnya dokumen standar penilaian di sekolah berdasarkan hasil studi dokumentasi oleh peneliti. Hasil angket kepala sekolah menunjukkan bahwa semua pernyataan mendapatkan skor tertinggi dan persentase untuk standar penilaian mendapai $100 \%$. Hasil angket guru menunjukkan kategori sangat baik dengan persentase $94 \%$. Standar penilaian jika dilihat dari hasil angket responden guru dan kepala sekolah telah dicapai dengan skor dan kategori yang maksimal, yaitu sangat baik.

Hasil wawancara dari informan kepala sekolah juga memperlihatkan kepala sekolah telah melaksanakan fungsi manajerial pada pengelolaan standar penilaian pendidikan dengan baik dan optimal. Kondisi tersebut terlihat pada jawaban yang diutarakan oleh kepala sekolah bahwa terkait masalah proses penilaian pendidikan menurutnya sangat penting. Menurut penjelasannya, untuk mendapatkan nilai yang baik dan berkualitas tentu harus didasari dengan proses yang baik dan bekualitas. Pertama dengan menetapkan KKM mata pelajaran dan KKM sekolah. Persoalan penilaian juga terkait masalah proses penyusunan naskah soal, mulai dari kisi-kisi, konsep soal dan uji validitas soal, objektivitas. Proses penyusunan perangkat penilaian baik itu penilaian sikap, pengetahuan maupun keterampilan harus dilaksanakan dengan perencanaan yang baik dan matang agar menjadi produk penilaian yang baik dan dapat dipertanggungjawabkan.

Hasil wawancara dengan informan guru terlihat bahwa pelaksanaan penilaian pendidikan telah dilaksanakan dengan baik dan optimal. Informan juga menjelaskan bahwa kelengkapan penilaian telah dibuat lengkap sesuai bimbingan dari kepala sekolah.

e. Manajemen Standar Pendidik dan Tenaga Kependidikan

Hasil perhitungan skor angket untuk responden kepala sekolah dan guru menunjukkan persentase $63 \%$ untuk responden kepala sekolah dan $86 \%$ untuk responden guru (Gambar 5).

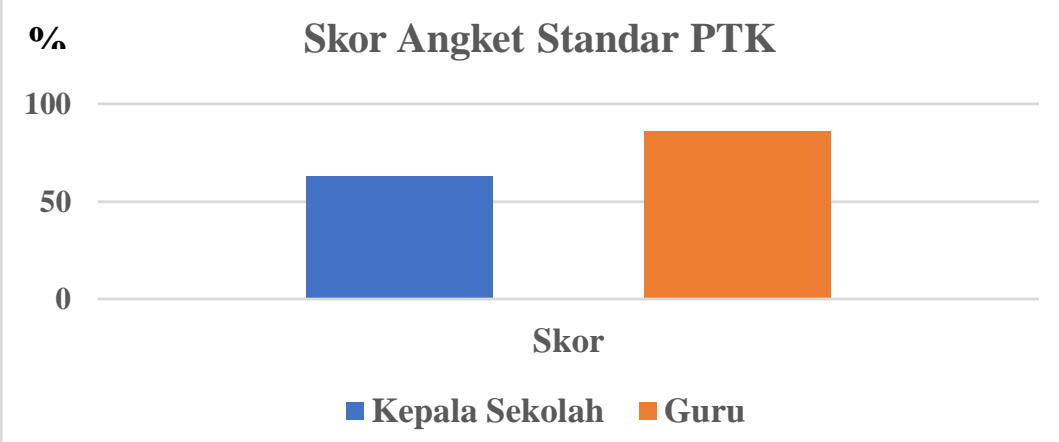

Gambar 5. Diagram Hasil Manajemen Standar Pendidik dan Tenaga Kependidikan SD Negeri 1 Gumelar

Y. Kurniawan, A. Andriani \& T. Taniredja, Manajemen Peningkatan Mutu SD Negeri 1 Gumelar Sebagai Sekolah Unggulan di Kecamatan Gumelar Kabupaten Banyumas 
Gambar 5 menunjukkan bahwa manajemen peningkatan mutu dari hasil rekapitulasi angket untuk standar pendidik dan tenaga kependidikan menunjukkan kategori baik untuk responden kepala sekolah dan kategori sangat baik untuk responden guru. Kondisi tersebut didukung oleh lengkapnya dokumen standar pendidik dan tenaga kependidikan di sekolah berdasarkan hasil studi dokumentasi oleh peneliti. Data yang ada menunjukkan bahwa semua guru dan kepala sekolah sudah memiliki kualifikasi akademik S1, bahkan ada seorang guru yang sudah berkualifikasi S2 dan merupakan guru berprestasi tingkat Kabupaten Banyumas tahun 2010. Standar pendidik dan tenaga kependidikan berdasarkan angket kepala sekolah menunjukkan kategori baik, karena berdasarkan pernyataan yang ada pada angket kepala sekolah untuk SDN 1 Gumelar tidak memiliki tenaga administrasi, laboratorium, dan perpustakaan yang khusus dan sesuai dengan kualifikasi akademiknya. Data dari angket guru menunjukkan kategori sangat baik, namun pada pernyataan ke- 7 dan 8 menunjukkan jumlah yang paling rendah yaitu 17. Jumlah skor paling tinggi pada angket responden guru untuk standar pendidik dan tenaga kependidikan yaitu 31 .

Hasil wawancara dari informan kepala sekolah juga memperlihatkan kepala sekolah telah melaksanakan fungsi manajerial pada pengelolaan standar pendidik dan tenaga kependidikan dengan baik dan optimal. Kondisi tersebut terlihat pada jawaban yang diutarakan oleh kepala sekolah bahwa terkait dengan standar pendidik dan kependidikan ada sedikit permasalahan. Penjelasan dari kepala sekolah bahwa untuk pendidik sudah $100 \%$ memenuhi ketentuan yang ada. Semua sudah S1 dan bahkan ada satu orang guru yang sudah S2. Permasalahannya yaitu tenaga kependidikan yang diantaranya tenaga administrasi, laboratorium dan perpustakaan belum sesuai, karena latar belakang pendidikan S1 tidak sesuai. Adapun tenaga administrasi sudah ada namun diampu oleh tenaga dengan kualifikasi Pendidikan S1 Program Studi Guru Kelas. Tenaga guru tersebut diberdayakan sebagai tenaga administrasi merangkap tenaga laboratorium dan perpustakaan. Sampai dengan hari ini permasalahan itu masih belum ada pemecahannya (tenaga kependidikan belum sesuai ketentuan). Bagaimanapun sampai dengan hari ini permasalaan itu masih menjadi persoalan yang belum dapat terselesaikan. Berbagai upaya ditempuh, motivasi dan dorongan tetap diupayakan agar keadaan tersebut dapat sesuai dengan ketentuan. Harapan demikian namun semua masih demikian dan dalam proses.

f. Manajemen Standar Sarana dan Prasarana

Hasil perhitungan skor angket standar sarana dan prasarana untuk responden kepala sekolah dan guru menunjukkan persentase $80 \%$ untuk responden kepala sekolah dan $89 \%$ untuk responden guru (Gambar 6). 


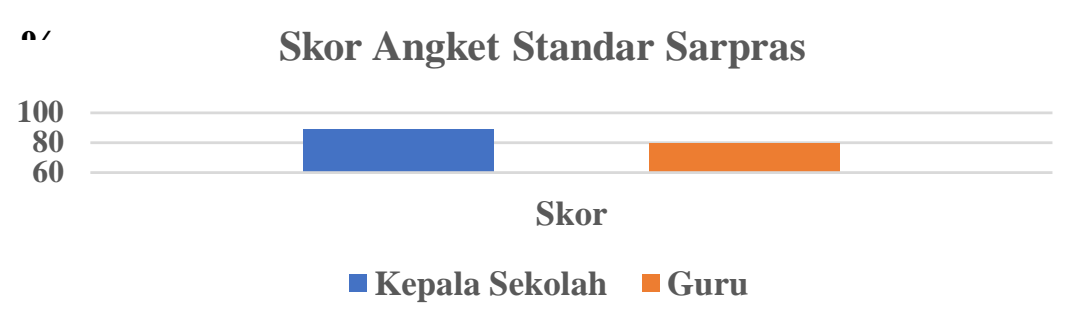

Gambar 6. Diagram Hasil Manajemen Standar Sarana dan Prasarana SD Negeri 1 Gumelar

Gambar 6 menunjukkan bahwa manajemen peningkatan mutu dari hasil rekapitulasi angket untuk standar sarana dan prasarana menujukan kategori sangat baik untuk responden kepala sekolah dan kategori baik untuk responden guru. Kondisi tersebut tidak jauh berbeda dari kondisi riil sarana dan prasarana yang ada di sekolah berdasarkan hasil pengamatan langsung peneliti.

Hasil wawancara dari informan kepala sekolah juga memperlihatkan kepala sekolah telah melaksanakan fungsi manajerial pada pengelolaan standar sarana dan prasarana dengan baik dan optimal. Kondisi tersebut terlihat pada jawaban yang diutarakan oleh kepala sekolah bahwa terkait sarana dan prasarana kami selalu mengupayakan agar semua dapat terpenuhi agar pelayanan pendidikan dapat terlayani dengan maksimal. Sarana dan prasarana seperti kelengkapan pembelajaran, alat peraga selalui kita upayakan melalui biaya-biaya yang dibenarkan menurut ketentuan yang berlaku. Sarana pendukung lain yang dapat difasilitasi oleh sekolah tentu kita fasilitasi.

Hambatan terkait sarana dan prasarana di SD Negeri 1 Gumelar diantaranya terkait ruang laborat, gudang, perpusatakaan. Sarana dan prasaran tersebut belum bida diadakan sesuai dengan ketentuan karena keterbatasan kemampuan sekolah. Sarana dan prasarana tersebut kita upayakan keberadaannya meskipun belum sesuai standar dan ketentuan. Kita mengadakan dan mengupayakan sesuai batas kemampuan pengadaan sekolah. Keterbatasan kemampuan itu kami upayakan melalui pengusulan pengadaan sarana dan prasarana kepada birokrasi terkait dalam hal ini dinas pendidikan kabupaten.

Wawancara terhadap guru menghasilkan kesimpulan bahwa sarana dan prasarana di SD Negeri 1 Gumelar sebagian besar telah terpenuhi. Adapun sarana dan prasarana yang belum terpenuhi seperti perpusatakaan yang sesuai dan memadai, ruang laboratorium, dan ruang gudang. Informasi dari guru, pihak sekolah, dalam hal ini kepala sekolah telah mengupayakan pengadaan sarana dan prasarana yang diimaksud melalui usulan kepada Dinas Pendidikan bagian Sarana dan Prasarana SD. Keterbatasan sarana dan prasarana yang belum terpenuhi tersebut tidak menjadi sebuah kendala yang berarti. Sekolah berusaha tetap memfasilitasi kebutuhan pelayanan terkait sarana dan prasarana yang belum 
terpenuhi tersebut melalui pengadaan sederhana sesuai dengan anggaran yang dibenarkan oleh aturan perundang-undangan yang berlaku.

g. Manajemen Standar Pengelolaan

Hasil perhitungan skor angket pada komponen standar pengelolaan menunjukkan persentase 100\% untuk responden kepala sekolah dan $95 \%$ untuk responden guru (Gambar 7).

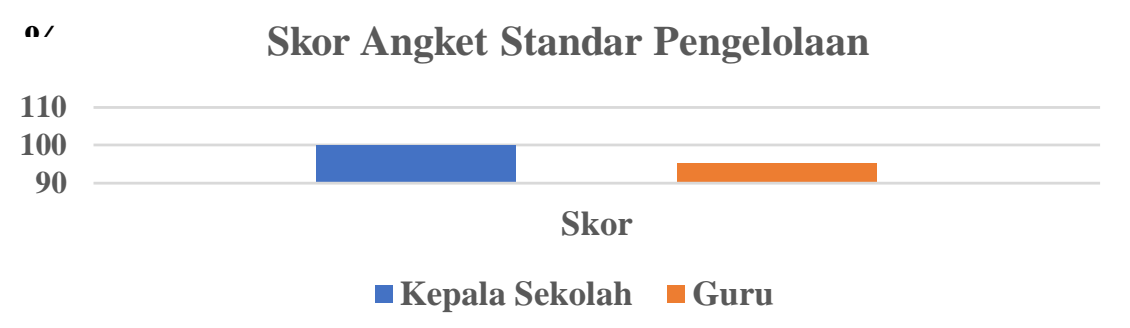

Gambar 7. Diagram Hasil Manajemen Standar Pengelolaan SD Negeri 1 Gumelar

Gambar 7 menunjukkan bahwa manajemen peningkatan mutu dari hasil rekapitulasi angket untuk standar pengelolaan menunjukkan kategori sangat baik baik untuk responden kepala sekolah maupun guru. Kondisi tersebut didukung oleh lengkapnya dokumen standar pengelolaan di sekolah berdasarkan hasil studi dokumentasi oleh peneliti.

Hasil wawancara dari informan kepala sekolah juga memperlihatkan kepala sekolah telah melaksanakan fungsi manajerial standar pengelolaan dengan baik dan optimal. Manajemen standar pengelolaan dilakukan dengan kolaboratif dan melibatkan pihak terkait serta selalu berpedoman pada prinsip-prinsip manajemen. Prinsip manajemen yang dimaksud adalah bahwa manajemen standar pengelolaan dilaksanakan melalui tahapan-tahapan kegiatan diantaranya: 1). merencanakan, 2) melaksanakan, 3) mengawasi, dan 4) melakukan evaluasi. Prinsip yang diungkapkan oleh kepala sekolah dalam mengelola sekolah seperti yang diungkapkann oleh Kompri (2014:3) bahwa tahapan manajemen terdiri dari 4 tahapan yaitu: 1) perencanaan, 2) pengorganisasian, 3) penggerakan, 4) pengawasan.

Semua komponen sekolah dilibatkan sesuai dengan tupoksinya masingmasing. Sebagai contoh dalam manajemen pengelolaan perpustakaan, kepala sekolah melibatkan tenaga perpustakaan, guru, karyawan, komite dan warga masyarakat sebagai upaya memaksimalkan mutu pelayanannya. Contoh lain diantaranya permasalahan PPDB dilaksanakan sesuai ketentuan, mulai dari kepanitiaan, kegiatan MOS, pembagian tugas guru, pemetaan kebutuhan satu tahun kedepan, menyusun rencana kerja sekolah, memetakan kebutuhan satu tahun ke depan, peningkatan kualitas dan mutu guru, prediksi diklat, workshop, langkah-langkah yang akan dilakukan berkaitan dengan lomba baik akademik maupun non akademik dan pembagian tugas pembimbingannya.

Y. Kurniawan, A. Andriani \& T. Taniredja, Manajemen Peningkatan Mutu SD Negeri 1 Gumelar Sebagai Sekolah Unggulan di Kecamatan Gumelar Kabupaten Banyumas 
Hasil wawancara terhadap informan guru menunjukkan bahwa manajemen pengelolaan dilaksanakan dengan baik. Kepala sekolah selalu melibatkan guru, tenaga kependidikan, dan komite sekolah dalam pelaksanaannya, oleh sebab itu SD Negeri 1 Gumelar menjadi sekolah unggulan di Kecamatan Gumelar. Dalam manajemen pengelolaan, kepala sekolah selalu memprioritaskan kegiatan yang primer berdasarkan hasil musyawarah dengan dewan guru, tenaga kependidikan dan karyawan sekolah. Kondisi tersebut membuat pelaksanaan pelayanan sekolah menjadi kondusif dan optimal.

h. Manajemen Standar Pembiayaan

Hasil perhitungan skor angket pada komponen standar pembiayaan untuk responden kepala sekolah dan guru menunjukkan persentase $100 \%$ untuk responden kepala sekolah dan 90\% untuk responden guru (Gambar 8)

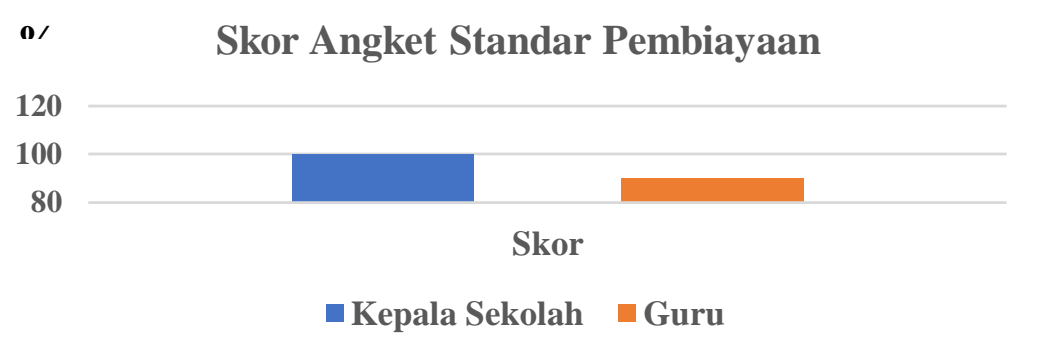

Gambar 8. Diagram Hasil Manajemen Standar Pengelolaan SD Negeri 1 Gumelar

Gambar 8 menunjukkan bahwa manajemen peningkatan mutu dari hasil rekapitulasi angket untuk standar pembiayaan menunjukkan kategori sangat baik baik untuk responden kepala sekolah maupun guru. Kondisi tersebut didukung oleh lengkapnya dokumen standar pembiayaan di sekolah berdasarkan hasil studi dokumentasi oleh peneliti.

Hasil wawancara dari informan kepala sekolah juga memperlihatkan kepala sekolah telah melaksanakan fungsi manajerial standar pembiayaan dengan baik dan optimal. Kondisi tersebut terlihat pada jawaban yang diutarakan oleh kepala sekolah. Deskripsi hasil wawancara dengan kepala sekolah menunjukkan bahwa sekolah telah melaksanakan manajemen pembiayaan dengan baik dan maksimal. Kepala sekolah menjelaskan bahwa sekolah bisa dikatakan hanya boleh mengelola keuangan yang hanya dari BOS. Penggunaan dari BOS tidak bias sesuai dengan keinginan kita. Sekolah harus mengikuti petunjuk teknis penggunaan BOS dan juga bisa mencari celah agar dapat menggali sumber dana pendidikan lain selain BOS sebagai aspek pendukung. Sebab jika kita harus berkata jujur kita akan mengalami kekuarangan jika hanya mengandalkan BOS. Karena ada anggaran yang tidak diperbolehkan dari dana BOS. Sekolah mencari solusi lain, sebagai contoh kita mengajak komite sekolah, alumni, tokoh masyarakat sebagai sumber-sumber yang dapat kita manfaatkan sebagai bentuk peran serta masyarakat sebagai salah satu 
bentuk kepedulian terhadap pendidikan terutama di SDN 1 Gumelar. Sepanjang dikomunikasikan dengan baik dan terbuka dengan orang tua wali, mereka siap memberikan bantuan yang sifatnya sukarela.

Wawancara dengan guru memperlihatkan bahwa sekolah telah melaksanakan manajemen standar pembiayaan dengan optimal. Informan guru menjelaskan bahwa kepala sekolah mengelola pembiayaan sekolah selalu berpedoman pada aturan terbaru yang berlaku. Kegiatan pemantauan pengelolaan keuangan yang dilakukan bendahara sekolah juga dilakukan secara rutin dan berkala. Kegiatan supervisi dilakukan setiap akhir bulan yang dilakukan berbarengan dengan rapat kerja bulanan sekolah. Informan guru juga menjelaskan bahwa selain dari dana BOS, kepala sekolah juga aktif melaksanakan fungsi kewirausahaannya. Kepala sekolah menjalin kemitraan dengan berbagai pihak seperti komite sekolah, masyarakat dan para pengusaha yang ada di lingkungan sekolah untuk bersamasama memajukan sekolah.

2. Dampak Terhadap Prestasi Kejuaraan Lomba

Manajemen yang baik menghasilkan prestasi yang baik, kondisi tersebut terlihat berdasarkan data yang diperoleh terhadap manajemen standar kompetensi lulusan sekolah. Prestasi siswa dalam lomba siswa pada dua tahun terakhir, yaitu tahun 2018 dan 2019 sangat bagus, karena memperoleh menjadi juara umum di tingkat Kecamatan Gumelar (memperoleh tropi kejuaraan terbanyak tahun 2018 dan 2019).

Hasil penelitian mengenai manajemen peningkatan mutu SD Negeri 1 Gumelar sebagai sekolah unggulan terlihat pada kualitas manajemen delapan standar nasional pendidikan. Delapan standar nasional Pendidikan telah dikelola dengan baik dan menghasilkan peningkatan prestasi sekolah. Prestasi sekolah terlihat sangat baik pada prestasi lomba-lomba siswa. Prestasi lomba meraih hasil yang memuaskan dikarenakan sekolah melaksanakan bimbingan yang maksimal dan fokus yang dilakukan secara kolaboratif oleh guru-guru di SD Negeri 1 Gumelar. SD Negeri 1 Gumelar menjadi memperoleh kejuaraan lomba siswa terbanyak dan menjadi juara umum tingkat kecamatan pada tahun 2018 dan 2019.

3. Dampak Terhadap Hasil USBN Siswa Kelas VI

Hasil lulusan siswa kelas VI SDN 1 Gumelar dilihat dari capaian hasil USBN untuk tahun 2018 menunjukkan rata-rata untuk mata pelajaran Bahasa Indonesia 74,7, Matematika 55,0 dan IPA 70,6. Hasil USBN untuk tahun 2019 menunjukkan rata-rata untuk mata pelajaran Bahasa Indonesia 66,8, Matematika 56,7 dan IPA 64,5 . Hasil tersebut menunjukkan bahwa untuk nilai lulusan siswa kelas VI belum memperoleh hasil yang memuaskan, karena untuk peringkat lulusan SDN 1 Gumelar di Kecamatan Gumelar pada tahun 2019 hanya mencapai peringkat 25.

Prestasi SD Negeri 1 Gumelar dalam lomba siswa selalu menjadi yang terbaik di Kecamatan Gumelar. Menjadi yang terbaik dalam prestasi lomba ternyata tidak

Y. Kurniawan, A. Andriani \& T. Taniredja, Manajemen Peningkatan Mutu SD Negeri 1 Gumelar Sebagai Sekolah Unggulan di Kecamatan Gumelar Kabupaten Banyumas 
untuk hasil Ujian Sekolah Berstandar Nasional. Hasil USBN tahun 2018 dan 2019 menunjukkan bahwa SD Negeri 1 Gumelar belum mencapai prestasi yang memuaskan. Hasil USBN Tahun 2019 hanya mencapai peringkat 25 dari 32 Sekolah Dasar di Kecamatan Gumelar.

SD Negeri 1 Gumelar yang sebagai sekolah unggulan di Kecamatan Gumelar tentu bukan berarti tidak memiliki hambatan dalam mencapai prestasi. Kondisi masih belum maksimalnya hasil USBN di tahun 2018 dan 2019 menjadi salah satu bukti bahwa SD Negeri 1 Gumelar masih harus terus berupaya keras untuk dapat meraih prestasi hasil USBN yang maksimal. Kondisi tersebut tidak kemudian mejadikan SD Negeri 1 Gumelar bukan sebagai sekolah unggulan, karena seperti yang dijelaskan Setyaningsih (2017:139) dalam hasil penelitiannya bahwa mutu sekolah tidak hanya ditandai dengan capaian hasil dari nilai ujian dan tingginya tingkat kelulusan peserta didik. Indikator tersebut merupakan salah satu capaian hasil dari mutu input dan proses suatu sekolah. Mutu sekolah berarti mencakup seluruh aspek manajemen di sekolah, merujuk pada proses penyelenggaraan pendidikan bukan pada hasil dari penyelenggaraan pendidikan. Artinya SD Negeri 1 Gumelar memiliki kualitas manajemen sekolah yang unggulan, namun untuk hasil USBN 2018 dan 2019 belum mencapai hasil yang maksimal.

Prestasi hasil USBN yang belum maksimal pada dua tahun terakhir disebabkan karena beberapa faktor. Guru kelas VI dan kepala sekolah menjelaskan bahwa ada dua faktor utama yang menghambat maksimalnya prestasi hasil USBN. Faktor tersebut diantaranya faktor intrinsik dan ekstrinsik siswa. Faktor instrinsik yang paling mempengaruhi adalah motivasi belajar siswa yang masih rendah. Faktor ekstrinsik siswa yaitu siswa lebih asik bermain game online di HP. Rendahnya motivasi belajar siswa tersebut menurut keterangan guru kelas VI disebabkan oleh faktor ekstrinsik yaitu sebagian besar siswa laki-laki lebih asik bermain game online dari pada memikirkan belajar.

\section{SIMPULAN}

Berdasarkan hasil kajian pustaka dan hasil penelitian dapat disimpulkan bahwa : 1) Manajemen peningkatan mutu SD Negeri 1 Gumelar telah dilaksanakan dengan optimal oleh kepala sekolah dengan melibatkan guru, tenaga kependidikan, komite sekolah dan masyarakat. 2) Manajemen peningkatan mutu SD Negeri 1 Gumelar yang dilaksanakan dengan mengutamakan kerjasama dan kolaborasi antara kepala sekolah, guru, komite sekolah dan masyarakat dengan berpedoman pada aturan yang berlaku menghasilkan prestasi lomba yang sangat memuaskan. SD Negeri 1 Gumelar menjadi sekolah yang terbanyak memperoleh kejuaraan lomba di tingkat Kecamatan dan bahkan ada beberapa mata lomba yang memperoleh kejuaraan di tingkat provinsi. 3) Manajemen peningkatan mutu SD Negeri 1 Gumelar belum berdampak terhadap prestasi hasil USBN pada dua tahun

Y. Kurniawan, A. Andriani \& T. Taniredja, Manajemen Peningkatan Mutu SD Negeri 1 Gumelar Sebagai Sekolah Unggulan di Kecamatan Gumelar Kabupaten Banyumas 
terakhir, yaitu 2018 dan 2019. Kondisi tersebut menurut studi lapangan disebabkan karena faktor intrinsik dan ekstrinsik siswa.

\section{DAFTAR PUSTAKA}

Arbangi, dkk. 2016. Manajemen Mutu Pendidikan. Jakarta: Kencana

Arifin Zainal. 2014. Penelitian Pendidikan Metode dan Paradigma Baru. Bandung: Remaja Rosda Karya.

Aziz Amrullah. 2015. Peningkatan Mutu Pendidikan. STAI Pancawahana Bangil. 10 (2): 1-13.

Badan Akreditasi Nasional Sekolah/Madrasah Jateng. 2018. Surat keputusan Badan akreditasi nasional seko lah/madrasah Provinsi: Jawa Tengah Nomor: 044/BANSM-JTG/SK/X/2018 tentang Penetapan Hasil dan Rekomendasi Akreditasi Sekolah/Madrasah. Semarang. BAN-SM.

Bafadal, Ibrahim. 2009. Manajemen Peningkatan Mutu Sekolah Dasar: Dari Sentralisasi Menuju Desentralisasi. Jakarta: Bumi Aksara.

Badan Akreditasi Nasional Sekolah/Madrasah. 2018. Hasil Akreditasi Sekolah/Madrasah. Tersedia: https://bansm.kemdikbud.go.id. Diunduh pada 2 April 2019.

Dirjen Dikdasmen Kemdikbud RI. 2016. Petunjuk Pelaksanaan Penjaminan Mutu Pendidikan oleh Satuan Pendidikan 2016. Jakarta: Kemdikbud RI.

Fauzi Ahmad. 2017. Manajemen Pendidikan Islam di Pesantren; Berbasis Kearifan Lokal Kajian Fenomenologis. Universitas Negeri Malang, 1 (1): 51-62.

Karyoto. 2016. Dasar-Dasar Manajemen - Teori, Definisi dan Konsep. Yogyakarta: CV. Andi Offset.

Kompri. 2014. Manajemen Pendidikan 2. Bandung: Alfabeta.

Mustari, M dan Rahman Taufik, M. 2014. Manajemen Pendidikan. Jakarta: Raja Grafika Persada.

Peraturan Pemerintah No. 19 Tahun 2005.

Peraturan Menteri Pendidikan dan Kebudayaan RI No. 28 Tahun 2016.

Raharjo Sabar B dan Yuliana L. 2016. Manajemen Sekolah untuk Mencapai Sekolah Unggul yang Menyenangkan: Studi Kasus di SMAN 1 Sleman Yogyakarta. Balitbang Kemdikbud dan UNY. 1 (2): 203-217.

Rahmah Syarifah. 2016. Mengenal Sekolah Unggulan. STAIN Malikussaleh Lhokseumawe. 7 (1): 11-22.

Saputri Evi R.I dan Haryanto Samsi. 2016. Manajemen Kultur Sekolah Dalam Upaya Peningkatan Mutu Pendidikan di SMA Negeri 2 Brebes. Universitas Sarjanawiyata Tamansiswa Yogyakarta, 4 (1): 77-84.

Setiyaningsih Charisma D. 2017. Status Akreditasi dan Kualitas Sekolah di Sekolah

Dasar Negeri. PGTK AL-Falah Batu. 1(2): 138-145 
Sugiyono. 2014. Metode Penelitian Kuantitatif Kualitatif dan $R \& D$. Bandung: Alfabeta.

Sukmadinata Nana S. 2016. Metode Penelitian Pendidikan. Bandung: Remaja Rosda Karya.

Sutapa Mada \& Andriani Dwi Esti. 2014. Studi Manajemen Pendidikan: Kajian Teoritis \& Praktis. Universitas Negeri Yogyakarta. 1 (1): $69-87$.

Tim Penyusun Kamus Pusat Pembinaan dan Pengembangan Bahasa. 2005. Kamus Besar Bahasa Indonesia. Jakarta: Balai Pustaka.

Undang-Undang Sistem Pendidikan Nasional No. 20 Tahun 2003. 